\title{
INTERGENERATIONAL MOBILITY
}

\section{AND ENTREPRENEURSHIP IN URUGUAY*}

\author{
NÉstor GANDELMAN ${ }^{* *}$ \\ Virginia RoBANo **
}

\begin{abstract}
We estimate the relationship between parents' education and income and children's schooling in Uruguay (1982-2010), interpreting this as a measure of intergenerational social mobility. Using three methodologies we report that such mobility has decreased over time. Improvements in education in the 1980s and 1990s were unevenly distributed. Computing an index of inequality of opportunity, we show that for mandatory education, this has remained constant, and for non-mandatory education, the increasing trend in inequality observed during the 1990s stagnated in the early 2000 s. Finally, using instrumental variables we find that entrepreneurship is associated with greater social mobility.
\end{abstract}

JEL classification: I24, J62, L26

Keywords: intergenerational social mobility, entrepreneurship, inequality of opportunity

\section{INTRODUCTION}

The relationship between entrepreneurship and social sectors defined by income level is a subject of debate. Some argue that the middle sectors are important for development because they are the source of entrepreneurship and innovation, contributing to employment creation and productivity growth (Acemoglu and Zilibotti, 1997). Successful entrepreneurs move up the income and social ladders, while unsuccessful entrepreneurs are at risk of moving down those ladders. If the middle sectors are truly the cradle of entrepreneurship, they could be the group experiencing the greatest social mobility within a country. However, other authors do not believe this to be the case and they emphasize that the middle sectors are merely the country's well-paid salaried workers (Banerjee and Duflo 2007). In a view that represents the middle-ground between these two perspectives, a

\footnotetext{
* The authors would like to thank Daniel Bukstein, Eduardo Lora, Francesca Castellani, Francisco Ferreira and participants in the Inter-American Development Bank workshop "Strengthening Mobility and Entrepreneurship: A Case for the Middle Classes" for their helpful comments and suggestions. All errors and omissions are solely the authors'.

** Nestor Gandelman (gandelman@ort.edu.uy) is the Director of the Department of Economics at Universidad ORT Uruguay.

*** OECD, Centre for Entrepreneurship, SMEs and Local Development. Correspondence: virginia. robano@oecd.org.
} 
distinction can be made between "opportunity entrepreneurs," that is, those who take advantage of unexploited business opportunities, and "necessity entrepreneurs," that is, those who are mostly associated with the informal sector, with fewer possibilities of generating positive externalities (Acs 2006). Necessity entrepreneurs are less likely to find a reasonably well-paid job in the labor market, turning to self-employment in low-productivity activities. The expected social mobility of opportunity entrepreneurs and necessity entrepreneurs is different.

In this paper, we use household survey data to analyze the relationships between entrepreneurship and intergenerational mobility in Uruguay for the period 1982-2010. We are interested in the effects of opportunity entrepreneurs; for that reason our working definition of entrepreneurship is business owners with employees. Necessity entrepreneurs tend to be engaged in subsistence and informal activities and are therefore not likely to have employees. By defining as entrepreneurs anyone with at least one employee, we proxy for those beyond subsistence levels and with some further entrepreneurial skills that can be linked to opportunity entrepreneurs.

Uruguay has some particularly interesting characteristics for a study of entrepreneurship and social mobility. Traditionally, Uruguay has been considered a country with a strong and stable middle class comprised mostly of European immigrants and their descendants. Many of these immigrant families have histories of social ascendance. Although many of the immigrants to Uruguay had low levels of education, they managed to prosper and their children's attainment far surpassed that of their parents.

The public school system initially developed in the final decades of the $19^{\text {th }}$ century acted as a melting pot; differences in social origin were somewhat diluted. However, in recent decades there have been signs that social interaction has lessened, with increased segregation and marginalization of the poor. The latest international educational performance tests administered to Uruguayan students (the PISA ${ }^{1}$ study) yielded disappointing results. Educational performance in public schools has worsened compared to outcomes obtained in the growing private education sector. Bukstein and Sapelli (2011) find that between the 2003 and 2009 PISA rounds, there was an increase in 
opportunity inequality. Vegas and Petrow (2008) show that along with income inequality, Uruguay has extreme educational inequality. This evidence suggests that the education system is no longer compensating for differences in origin. Furthermore, the education system may actually be perpetuating these differences.

As of today, there is no survey data for individuals over time. Therefore, to measure intergenerational mobility we use educational attainment as a proxy for social mobility, comparing parents' educational attainment with the lag in schooling that their children present. This methodology was initially developed by Behrman et al. (1999) as a technique to follow individuals through time when panel surveys are not available. It has been used, among others, by Andersen (2001) for the case of Bolivia, by Conconi et al. (2008) for a comparative analysis of several Latin American countries, by Azevedo and Boullion (2010) for a review of the Latin American evidence, and by the Organization for Economic Co-operation and Development for its 2011 Latin American Outlook (OECD, 2011).

The latest developments in the field have shown that although this technique is ingenious, it does not completely overcome the potential endogeneity and simultaneity problems that focusing on income and educational attainment might present. Therefore, we complement the analysis using two techniques: First, as is traditional in the literature, we use instrumental variables (IV) to isolate the causal impact of entrepreneurship status (our main variable of interest) in the educational attainment of children living in a household with an entrepreneur. Moreover, we follow Ferreira and Gignoux (2011) and present an index of inequality of opportunity, which while acknowledging the potential pitfalls of the social mobility index (SMI), measures the overall effect of entrepreneurship, income, and parental educational attainment (the circumstances beyond a child's control) on children's schooling.

In addition, we calculate transition matrices that show the probability of educational attainment of children, conditional on their parents' educational attainment. From these matrices we calculate the existing probabilities of upward, downward, and educational immobility and their trends over time.

All three methodologies consistently find that in Uruguay, there were decreasing levels of mobility from 1982 until the early 2000s. In the latest years of the study, this decreasing mobility trend seems to have 
stabilized. With respect to entrepreneurship, we find that it is indeed a channel for higher intergenerational social mobility.

The paper proceeds as follows: In Section 2 we present in detail the methodologies used and in Section 3 we present the data and specific definitions. In Section 4 we report the results, while Section 5 contains concluding remarks.

\section{Methodologies}

To better understand the relationship between entrepreneurship and intergenerational mobility, we first introduce a social mobility index. Recognizing that there may be problems of endogeneity and simultaneity, we improve the estimations in two ways: First we apply the instrumental variable technique to the estimations of the schooling gap (the difference between the years of schooling that a child should have, according to his or her age, and the actual years of schooling that the child has, hereinafter SG), and second, we compute an index of inequality of opportunity. Finally, we calculate the ex-ante probabilities of educational attainment of a child, conditional on his/her parents' educational attainment. The methodologies are described below.

\subsection{Social mobility}

\section{The impact of parents' schooling on children's schooling}

We compute a social mobility index (SMI) that measures the intergenerational transmission of educational attainment from parents to children. As we mentioned, this methodology was initially developed by Behrman et al. (1999) and provides a way of measuring social mobility in cases where surveys that follow individuals over time are unavailable. The SMI is an indicator of future opportunities for children in families, based on household income and parental education. The basic postulate underlying this methodology is that if family background, i.e., parents' education and income, is important in determining opportunities for children, then social differences are perpetuated, i.e., there will be a low level of inter-generational mobility within the society. However, if family background is not decisive in explaining educational outcomes, the education system is functioning as a homogenizing device, allowing for greater social mobility. With this methodology, we speak of determining in a 
loose sense. Since we lack an identification strategy, the relationship between family background and children's education outcome should not be interpreted in causal terms. ${ }^{2}$ Acknowledging this caveat, we present two measures that control for potential endogeneity. We keep the SMI results in order to build intuition, as the presence of correlation is an important predictor of the existence of causality (Angrist and Pischke, 2009).

The proxy to measure future opportunities is the schooling gap (SG), which measures years of missing education. It is calculated as the difference between the child's age minus 6 minus years of education.

The first step in computing the SMI index is to run a set of ordinary least squares (OLS) regressions on all school-aged children. We run one regression for each year from 1982 to 2010. The main covariates used are those related to family background: per-capita household income, $y$, and maximum educational attainment of the parents, $E$. We include a broader set of covariates $(X)$, that may affect the child's schooling gap, i.e., whether there are siblings in the household, the birth order of the child for whom the SG is calculated, and whether the child lives in a single-parent household.

$$
S G_{i}=\alpha+\beta_{0} E_{i}+\beta_{1} y_{i}+X_{i}^{\prime} \Pi+u_{i}
$$

To Equation (1), we apply the Fields (2003) decomposition ${ }^{3}$, which breaks down inequality in the schooling gap into a factor inequality weight (FIW) for each of the explanatory variables. This decomposition has several properties.

In particular, it yields a unique decomposition rule irrespective of the inequality index used (e.g., the variance of the dependent variable as in this paper or the Gini index, and so on), provided that the inequality index is continuous, symmetric, and takes the value of zero when all observations are identical. The sum of all weighting factors adds up the R-squared coefficient of the regression. After some additional manipulation, the FIW can be expressed as the product of the estimated coefficient of each variable, its standard deviation, and the correlation coefficient between the variable and the schooling gap, divided by the

2. See Haveman and Wolfe (1995) for a review of the older literature and Holmlund et al. (2011) for more recent literature, including limits to causal inference.

3. The Fields (2003) decomposition, in turn, builds on Shorrocks' (1982) implementation of the Shapley (1953) income decomposition. 
standard deviation of the schooling gap itself. For example, the FIW for educational attainment is calculated as:

$$
S E_{t}=\frac{\beta_{0} \sigma\left(E_{t}\right) \operatorname{corr}\left(E_{t}, S G_{t}\right)}{\sigma\left(S G_{t}\right)}
$$

The SMI is the difference between one minus the proportion of the SG explained by the family background.

$$
S M I_{t}=1-\frac{\beta_{0} \sigma\left(E_{t}\right) \operatorname{corr}\left(E_{t}, S G_{t}\right)}{\sigma\left(S G_{t}\right)}-\frac{\beta_{1} \sigma\left(y_{t}\right) \operatorname{corr}\left(y_{t}, S G_{t}\right)}{\sigma\left(S G_{t}\right)}
$$

We compute the SMI for two age subgroups: 6-15 and 16-23. In Uruguay, all children are required to attend school until the third year of secondary education. This defines the first age group. The second age group contains individuals who continue to study beyond this mandatory educational level. Since we need data on parents' education, we can only consider those individuals who live with their parents. This may induce certain biases in our computation since those living with their parents, especially for the older group, are not likely to be a random sample of the population of their cohort. In our estimations, the proportion of children aged 16-23 who are living with their parents is $88 \%$.

\section{Differences in the social mobility index}

The methodology described above could be extended to address the impact of entrepreneurship. In order to do that, we have to add several interactions to proxy for entrepreneurship status to Equation (1). The augmented equation is:

$$
S G_{i}=\alpha+\beta_{0} E_{i}+\beta_{1} y_{i}+\beta_{0 e} E_{i} \mathrm{I}_{e i}+\beta_{1 e} y_{i} \mathrm{I}_{e i}+X_{i}^{\prime} \Pi+\gamma_{e} \mathrm{I}_{e i}+u_{i}
$$

where $\mathrm{I}_{e}$ indicates that the household's main income is provided by an entrepreneur.

Once Equation (4) is estimated, the impact of parents' income and education on the SG are:

$$
\frac{\partial S G}{\partial y}=\hat{\beta}_{1}+\hat{\beta}_{1 e} \mathrm{I}_{e}
$$




$$
\frac{\partial S G}{\partial E}=\hat{\beta}_{0}+\hat{\beta}_{0 e} \mathrm{I}_{e}
$$

The impact of family background depends on the entrepreneurship status of the household. In this manner, the SMI for entrepreneur households can be computed as:

$$
\begin{gathered}
S M I_{t}=1-\frac{\beta_{0} \sigma\left(E_{t}\right) \operatorname{corr}\left(E_{t}, S G_{t}\right)}{\sigma\left(S G_{t}\right)}-\frac{\beta_{1} \sigma\left(y_{t}\right) \operatorname{corr}\left(y_{t}, S G_{t}\right)}{\sigma\left(S G_{t}\right)} \\
-\frac{\beta_{0 e} \sigma\left(e_{t} E_{t}\right) \operatorname{corr}\left(e_{t} E_{t}, S G_{t}\right)}{\sigma\left(S G_{t}\right)}-\frac{\beta_{1 e} \sigma\left(e_{t} y_{t}\right) \operatorname{corr}\left(e_{t} y_{t}, S G_{t}\right)}{\sigma\left(S G_{t}\right)}
\end{gathered}
$$

Meanwhile, the SMI for non-entrepreneurs is still reflected by Equation (3).

In the results section, we first present the family characteristics (Equation 3) and then introduce the interaction with entrepreneurship (Equation 4). The rationale for sequentially including the interactions is to facilitate the analysis of the coefficient on entrepreneurship. We improve the OLS estimations using 2SLS, first identifying entrepreneurship status based on the characteristics of the head of household (age and gender) and then using the predicted value to estimate the schooling gap. Using instrumental variables (age and gender), we causally identify the effect of entrepreneurship on the schooling gap for the two age groups analyzed.

\section{Inequality of opportunity}

Our second methodology for addressing the presence of endogeneity follows Ferreira and Gignoux (2011). The authors conduct a study analyzing different educational achievements in a sample of countries, as measured by the PISA scores. They claim that apart from effort, circumstances (family background in our terminology) of the students also partially explain differences in the observed results. To show this, they construct an index of inequality of opportunity (IOp) based on an OLS regression of children's educational attainment on their set of circumstances $(C)$, which in our context is described in Equation $(1)^{4}$, where the circumstances comprise parents' educational attainment 
and income and the set $X$ of covariates. This methodology overcomes the problem of endogeneity and simultaneity that the coefficients of parental income and education might present in explaining the educational attainment of children.

The IOp is thus:

$$
\mathrm{IOp}=\left(\frac{\operatorname{Var}(C \beta)}{\operatorname{Var}(S G)}\right)
$$

Thus, following Ferreira and Gignoux (2011), we compute an IOp for the two age groups in our sample. We maintain the use of the sample variance as our chosen inequality measure. The idea is that the percentage of the SG that is explained by circumstances that do not depend on the child is a measure of the differences in opportunities among children. This index is different from the SMI in that it is not only concerned with family background variables, but also considers all circumstances (and their simultaneous interactions) that could affect a child's performance.

\subsection{Transition matrices}

We present a set of transition matrices that show the probability of children's educational attainment conditional on their parent's educational attainment. The rows of the matrix represent parental educational attainment and the columns represent children's educational attainment. Thus, $t_{i j}$ when $i=j$ shows the ex-ante probability that a child has of completing exactly the same level of education as his/her parents. Whenever $i>j$, the matrix shows the ex-ante probability that a child has of completing a lower level of education than his/her parents, and analogously for $i<j$.

We divide educational attainment into three categories: primary education or less; some secondary school; and completed secondary school and higher. Let $T$ be a $3 \times 3$ transition matrix,

$$
T=\left[\begin{array}{ccc}
t_{11} & t_{12} & t_{13} \\
t_{21} & t_{22} & t_{23} \\
t_{31} & t_{32} & t_{33}
\end{array}\right] .
$$


Note that

$$
\sum_{i} \sum_{j \neq i} t_{i j}=1
$$

The matrices can be used to show upward and downward mobility. The upward mobility index is the ex-ante probability that children achieve at least their parents' educational attainment. The downward mobility index is the ex-ante probability that children achieve equal or lower educational attainment as their parents. The immobility index is the probability that children have the same educational attainment as their parents. Formally:

$$
\begin{aligned}
& I_{\text {up }}=t_{11}+t_{12}+t_{13}+t_{22}+t_{23}+t_{33} \\
& I_{\text {down }}=t_{11}+t_{21}+t_{22}+t_{31}+t_{32}+t_{33} \\
& I_{\text {inmobility }}=t_{11}+t_{22}+t_{33}
\end{aligned}
$$

Since Uruguayan household surveys do not gather information about the parents' background, we construct it only for children between the ages of 19 and 23 living with their parents. The surveys show that $81 \%$ of individuals in that age range live with their parents. This induces two sources of biases: differences in the distribution of parent's education and differences in the children's educational achievement between those living with or without their parents. The first arises if parents' education is associated with different patterns of abandonment of the parental home. The second arises if those who left their parental homes have a different educational achievement than those who stayed home. To partially address this bias we implement the Ferreira and Gignoux (2011) inverse probability weighting technique. This consists basically of reweighting the groups defined by children's education to mimic the national distribution (without considering whether they live with their parents). In doing so we are implicitly assuming that the distribution of parental education among those who do not live with their parents is the same as the distribution of parental education among those who still live with them. 


\section{DATA AND DEFINITIONS}

\subsection{Data}

The data come from household surveys (Encuesta Continua de Hogares, ECH) conducted by the National Institute of Statistics (INE). These surveys, conducted annually, ask about household composition, including the age, gender, educational attainment, and labor market variables of household members, among other indicators. We accessed data from 1982 to 2010. The household surveys cover the capital city of Montevideo and other urban areas, i.e., areas with more than 5,000 inhabitants, in the rest of the country. The INE only began gathering information for rural settings in 2006; for comparison reasons these settings are not covered in this paper.

\subsection{Definitions of entrepreneurs' households}

What constitutes an entrepreneur is a critical definition; here, we are interested in the effects of opportunity entrepreneurs rather than necessity entrepreneurs. Using household surveys, this distinction is empirically difficult to make because there are no good proxy variables that are also uncorrelated with income and income mobility.

In this paper, we follow the EUROSTAT-OECD definition of an entrepreneur as "those persons (business owners) who seek to generate value through the creation or expansion of economic activity, by identifying and exploiting new products, processes or markets." ${ }^{5}$ In our operational definition of an entrepreneur, we add the restriction of employing at least one person.

Those who operate their own business but who do not have any employees, i.e., the self-employed, are probably necessity entrepreneurs and are therefore not included in our definition of entrepreneurs. Bukstein and Gandelman (2014) consider two dimensions in their classification of opportunity and necessity entrepreneurs; income risks and size of the group over the business cycle. They present evidence for business owners with employees, and for two groups of self-employed persons: those without a fixed workplace and those with a fixed workplace. They conclude that business owners with employees behave like 
opportunity entrepreneurs in that they take more risks and follow the business cycle, i.e., in booms there are more business opportunities than in recessions. On the other hand the self-employed without fixed workplaces are classified as necessity entrepreneurs, with lower levels of income and lower income volatility. The self-employed with a fixed workplace do not face large risks due to income variability, but the size of the group changes with the business cycle.

Finally, we consider that a household belongs to the entrepreneurial sector when its main source of income is the entrepreneurial activity of one of its members.

\section{Results}

Before reporting the results of our estimations, we present a series of tables with descriptive statistics by entrepreneurship status.

\subsection{Descriptive results}

Table 1 presents the percentage of entrepreneurs by income sector for two extreme years in this study. It is difficult to evaluate what is a low or high level of entrepreneurship for any given country. In 2010, in only $6.75 \%$ of the households in Uruguay the main income provider is an entrepreneur. Kantis et al. (2012) used the same operational definitions that we use for several Latin American countries. Comparing our results with theirs, we find that Uruguay has about the same level of entrepreneurship activity as Brazil, a bit more than Argentina, but less than Ecuador.

Table 1. Entrepreneur status by social sector, 1984 and 2010

\begin{tabular}{|c|c|c|c|c|c|c|c|c|}
\hline & \multicolumn{2}{|c|}{ Disadvantaged } & \multicolumn{2}{|c|}{ Middle } & \multicolumn{2}{|c|}{ Affluent } & \multicolumn{2}{|c|}{ All } \\
\hline & 1984 & 2010 & 1984 & 2010 & 1984 & 2010 & 1984 & 2010 \\
\hline $\begin{array}{l}\text { Number of households } \\
\text { with an entrepreneur }\end{array}$ & 1322 & 212 & 1762 & 4551 & 64 & 2248 & 3148 & 7011 \\
\hline$\%$ of social sector & 2.71 & 1.06 & 13.93 & 6.23 & 32.49 & 20.91 & 5.11 & 6.75 \\
\hline \multicolumn{9}{|c|}{$\begin{array}{l}\text { Source: Authors' calculations based on household surveys. } \\
\text { Note: Following Lopez-Calva and Ortiz-Juarez (2011) the middle sector is composed of those households } \\
\text { with per-capita daily income between US } \$ 10 \text { and US } \$ 50 \text {, adjusted for purchasing power parity, at } \\
\text { constant } 2005 \text { prices. Those earning below the US } \$ 10 \text { threshold are the disadvantaged and those earning } \\
\text { above US } \$ 50 \text { are considered affluent. }\end{array}$} \\
\hline
\end{tabular}


Figure 1 presents the evolution of entrepreneurship in percentages by social sector over time. The distribution of entrepreneurs among social sectors is uneven, as is the proportion of entrepreneurs within sectors. Overall, the proportion of entrepreneurs has been decreasing since 1982. While most entrepreneurs belong to the middle sector, i.e., more than $70 \%$ in 2010, entrepreneurship is proportionately stronger in the affluent sector. There is a noticeable decrease after 1999, with a low point in 2003, after which a recovery in entrepreneurship activity starts following the recovery of national growth.

\section{Figure 1. Entrepreneurship over time by social sector}

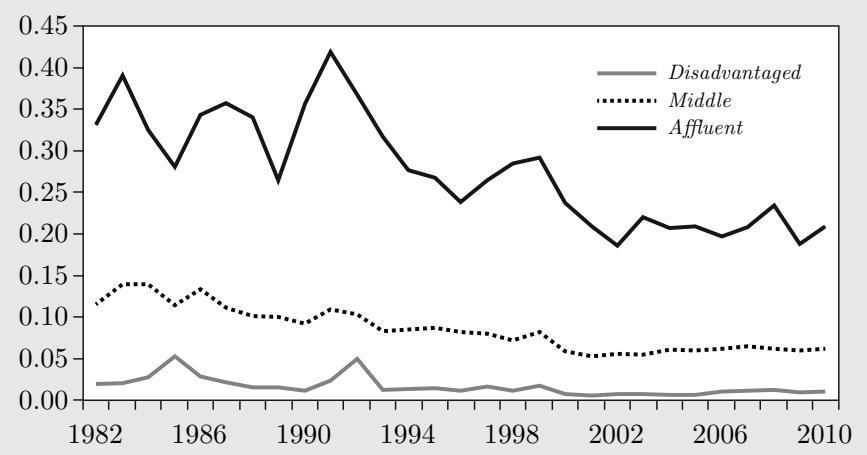

Source: Authors' calculations based on household surveys

Note: The middle sector is composed of those households with per-capita daily income between US\$10 and US\$50, adjusted for purchasing power parity, at constant 2005 prices. Those earning below the US\$10 threshold are the disadvantaged and those earning above US\$50 are considered affluent.

Table 2 reports several socio-demographic characteristics of entrepreneurs and the rest of the working population. Entrepreneurs have on average two more years of education than the rest of the population and are about three years older than non-entrepreneurs, which may be due to multiple reasons. On the one hand, it can take time for an individual to be able to start his or her own business, and typically the early work experience is gained working for others, rather than in one's own business. Alternatively, some individuals may inherit a family business, gaining experience in that business for several years until older family members retire, after which they take over. 
Table 2. Sociodemographic characteristics of households, by entrepreneurship status in 2010

(population 18 and older)

\begin{tabular}{lcc}
\hline & Not entrepreneur & Entrepreneur \\
Years of education & 9.10 & 11.37 \\
Age & 41.42 & 44.31 \\
\% female & 49 & 48 \\
Number of children & 3.77 & 3.12 \\
Capital city (Montevideo=1) & 0.54 & 0.40 \\
\hline Source: Authors' calculations based on household surveys. & \\
\hline
\end{tabular}

The improvement in education over time is shown in Table 3. Older individuals in all social sectors have less education than younger individuals; however, improvement in education is not homogenous among sectors. The average improvement in education is 0.5 years for the disadvantaged and 2.3 years for the affluent sector. Because of these uneven outcomes, differences in education have widened between sectors for all age groups. In 1984, an affluent individual had 1.94 more years of education than a middle sector individual, and 5.07 more years than a disadvantaged individual did. In 2010, these differences were 4.2 and 6.85 years, respectively, a sign of increased social segmentation that reduces social mobility. Without considering the quality of the education received, we report that there are quantity differentials that have been widening the gap between social sectors. Table 3 suggests that the education system is not successful in reducing opportunity inequality between social sectors.

\section{Table 3. Mean education by age and sector}

(in years)

\begin{tabular}{|c|c|c|c|c|c|c|c|c|c|c|c|c|}
\hline \multirow{2}{*}{ Age group } & \multicolumn{2}{|c|}{ 21-65 } & \multicolumn{2}{|c|}{ 21-25 } & \multicolumn{2}{|c|}{$26-35$} & \multicolumn{2}{|c|}{$36-45$} & \multicolumn{2}{|c|}{$46-55$} & \multicolumn{2}{|c|}{$56-65$} \\
\hline & 1984 & 2010 & 1984 & 2010 & 1984 & 2010 & 1984 & 2010 & 1984 & 2010 & 1984 & 2010 \\
\hline Disadvantaged & 6.63 & 7.14 & 8.37 & 8.02 & 7.83 & 7.55 & 6.72 & 7.25 & 5.61 & 6.89 & 4.88 & 6.11 \\
\hline Middle & 9.76 & 9.78 & 10.88 & 10.71 & 11.41 & 10.56 & 10.14 & 10.07 & 8.82 & 9.40 & 8.03 & 8.39 \\
\hline Affluent & 11.70 & 13.99 & 12.58 & 13.66 & 13.00 & 14.48 & 10.74 & 14.41 & 11.58 & 13.94 & 11.88 & 13.18 \\
\hline
\end{tabular}


In table 4, we present descriptive statistics of the SG by entrepreneurship status. The Table shows the SG for children enrolled in mandatory and non-mandatory education, i.e., ages 6-15 and 16-23 respectively. The differences between entrepreneur and non-entrepreneur households are statistically significant for both extreme points in time. This gap is especially large for non-mandatory education (about four years). Comparing just these two points in time, it seems that the gap between entrepreneur and non-entrepreneur households has decreased over time.

Overall, children of entrepreneurs have a smaller SG. A likely explanation for this is that opportunity entrepreneurs pass their higher abilities on to their children. Alternatively, given the association between entrepreneurship and the most affluent sectors of society, the smaller SG may be due to access to better schools that reduce their current $\mathrm{SG}$, giving them a stronger foundation and motivation to continue on to tertiary education.

Table 4. Schooling gaps for entrepreneurs

(difference of means)

\begin{tabular}{|c|c|c|c|c|c|c|}
\hline & \multicolumn{3}{|c|}{1984} & \multicolumn{3}{|c|}{2010} \\
\hline & $\begin{array}{c}\text { Not } \\
\text { entrepreneur }\end{array}$ & Entrepreneur & Difference & $\begin{array}{c}\text { Not } \\
\text { entrepreneur }\end{array}$ & Entrepreneur & Difference \\
\hline $\begin{array}{l}\text { Mandatory } \\
\text { education }\end{array}$ & 0.64 & 0.28 & $\begin{array}{c}0.36^{* * *} \\
(0.05)\end{array}$ & 0.55 & 0.26 & $\begin{array}{l}.29 * * * \\
(0.03)\end{array}$ \\
\hline $\begin{array}{l}\text { Non-mandatory } \\
\text { education }\end{array}$ & 4.28 & 2.79 & $\begin{array}{c}1.49 * * * \\
(0.16)\end{array}$ & 3.54 & 2.2 & $\begin{array}{c}1.34^{* * *} \\
(0.11)\end{array}$ \\
\hline
\end{tabular}

\subsection{Results from transition matrices}

Table 5 presents a transition matrix for selected years. We divide educational attainment into three categories: primary education or less; some secondary school; and completed secondary school and higher.

The top left figure in each matrix is the percentage of students who have parents with the lowest educational attainment whose children have similar levels. The bottom right figure is the percentage of students who have parents with the highest educational attainment whose children have similar levels. The figure in the bottom right cell has increased continuously over time while the one in the top left has decreased. Inspection of these numbers alone does not signal the evolution of mobility as the immobility index does. 
With respect to upward and downward mobility, in 1985, 71\% of children whose parents completed primary education and $37 \%$ of children whose parents had some secondary education outperformed their parents. Also in 1985, 7\% of children whose parents had some secondary education only finished primary school, while $37 \%$ of children whose parents had secondary or higher education did not complete secondary school.

\section{Table 5. Education transition matrix by year}

(children aged 19-23)

\begin{tabular}{|c|c|c|c|}
\hline \multirow{2}{*}{ Parents' education } & \multicolumn{3}{|c|}{ Children's education (\%) } \\
\hline & Primary or less & Some secondary & Secondary and higher \\
\hline \multicolumn{4}{|c|}{1985} \\
\hline Primary or less & 15 & 28 & 8 \\
\hline Some secondary & 2 & 18 & 12 \\
\hline Secondary and higher & 1 & 6 & 11 \\
\hline \multicolumn{4}{|c|}{1990} \\
\hline Primary or less & 14 & 29 & 8 \\
\hline Some secondary & 2 & 19 & 10 \\
\hline Secondary and higher & 0 & 5 & 11 \\
\hline \multicolumn{4}{|c|}{1995} \\
\hline Primary or less & 12 & 21 & 7 \\
\hline Some secondary & 4 & 20 & 11 \\
\hline Secondary and higher & 1 & 7 & 16 \\
\hline \multicolumn{4}{|c|}{2000} \\
\hline Primary or less & 11 & 16 & 5 \\
\hline Some secondary & 4 & 20 & 13 \\
\hline Secondary and higher & 1 & 8 & 20 \\
\hline \multicolumn{4}{|c|}{2005} \\
\hline Primary or less & 9 & 14 & 4 \\
\hline Some secondary & 4 & 20 & 9 \\
\hline Secondary and higher & 1 & 12 & 27 \\
\hline \multicolumn{4}{|c|}{2010} \\
\hline Primary or less & 8 & 15 & 3 \\
\hline Some secondary & 5 & 24 & 9 \\
\hline Secondary and higher & 1 & 14 & 21 \\
\hline
\end{tabular}


Figure 2 shows the immobility index and in Figure 3 we report the upward and downward mobility indices. Figure 2 indicates a trend toward increasing immobility, with a reversal from 2005 onward. Figure 3 shows a continuous yet modest worsening of the upward mobility index and a small increase in the downward mobility index. In 2010, about $87 \%$

\section{Figure 2. Inmobility index}

(in percent)

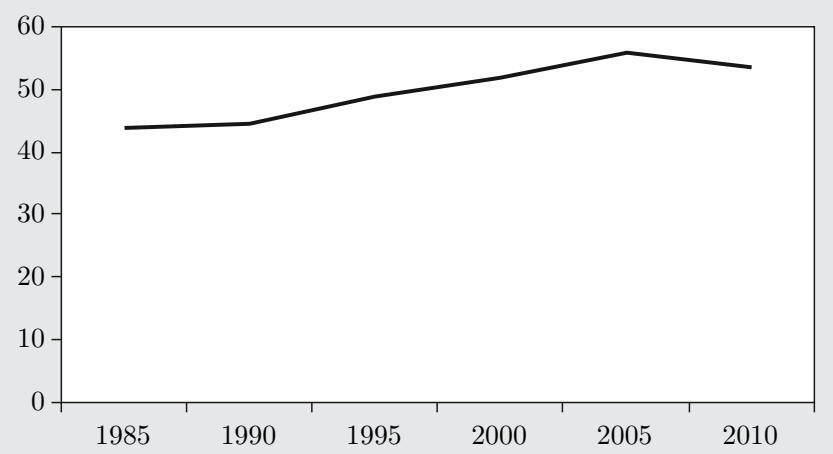

Source: Authors' calculations based on household surveys.

Figure 3. Upward and downward mobility indices (in percent)

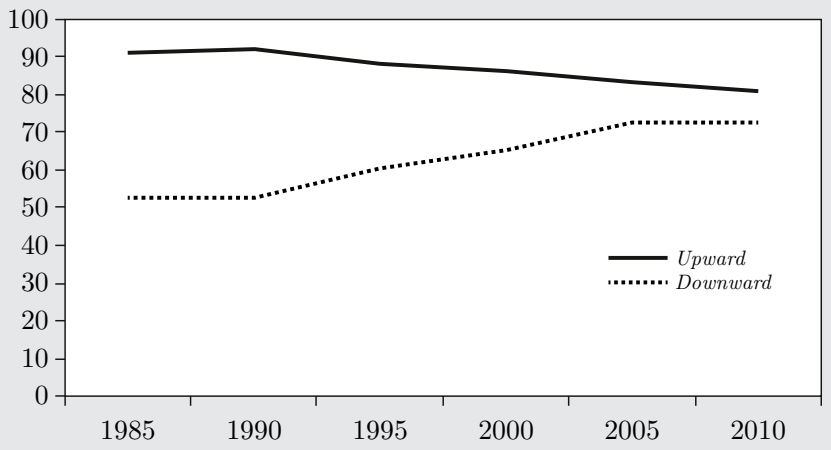


of children had achieved at least their parents' educational attainment, while in 1985 the figure was $91 \%$.

\subsection{Results from social mobility calculations}

The results reported so far do not control for joint determination and for the impact of other family background characteristics. As an illustration of the regressions behind the SMI, in Table 6 we present the SG estimation results for mandatory education for 2006. The first column shows the baseline estimation of the determinants of the SG with no distinction by entrepreneurship status, corresponding to Equation (1). According to the figures, both household income per capita and parental educational attainment are negatively correlated with the SG. The second column (Equation (4)), presents the determinants of the SG, distinguishing between entrepreneurs and others by incorporating a binary variable for entrepreneurs and relating this variable to parental income and educational attainment. The overall explanatory power of family background characteristics does not vary with the inclusion of entrepreneurship status, although the interaction terms of these variables with entrepreneurship have a positive sign. This means that for entrepreneurs, family income and education have a weaker relationship to the SG. One more year of parental education results in 0.07 fewer years of $\mathrm{SG}$ for the average individual. One more year of parental education is associated with 0.04 fewer years of SG for households with entrepreneurial activity.

In column 3 , we replicate the same estimation as in column 2 , but taking into account the potential endogeneity of the entrepreneurship decision. We implement an instrumental variable (IV) strategy, causally identifying the entrepreneurship decision with the age and gender variables as instruments. The first stage of the equation passes the exclusion restriction and identification tests, with an F-value of $53.12(p$-value $=0.00)$ and Angrist-Pischke chi-square test value of $318.89(p$-value $=0.00)$, indicating that the instruments are strong enough to identify the effect of entrepreneurship on the schooling gap. When controlling for the possible endogeneity of the entrepreneurship decision, we appreciate that the entrepreneurship variable is no longer significant in explaining the SG for mandatory education. The rest of the explanatory variables keep their magnitude and significance

compared to the OLS estimation in column 2. One explanation for the loss of significance might be that in Uruguay, mandatory education 
coverage is very extensive, and the effect of entrepreneurship is no longer large enough to alter results.

Analogous to Table 6, Table 7 contains the estimation results for the SG for non-mandatory education. The estimated coefficients of family background are almost four times higher in this case than for mandatory education. According to our expectations, the effect of entrepreneurship status is greater in the case of non-mandatory education. There is a negative relationship between entrepreneurship

\section{Table 6. Schooling gap in 2006}

(mandatory education)

\begin{tabular}{|c|c|c|c|}
\hline & $\begin{array}{l}(1) \\
\text { OLS }\end{array}$ & $\begin{array}{l}(2) \\
\text { OLS }\end{array}$ & $\begin{array}{l}\text { (3) } \\
\text { IV }\end{array}$ \\
\hline Household income per capita & $\begin{array}{c}-0.12 \\
(0.01)^{* * *}\end{array}$ & $\begin{array}{c}-0.12 \\
(0.01)^{* * *}\end{array}$ & $\begin{array}{c}-0.12 \\
(0.02)^{* * *}\end{array}$ \\
\hline Maximum level of parental education & $\begin{array}{c}-0.07 \\
(0.00)^{* * *}\end{array}$ & $\begin{array}{c}-0.07 \\
(0.00)^{* * *}\end{array}$ & $\begin{array}{c}-0.07 \\
(0.00)^{* * *}\end{array}$ \\
\hline Dummy for single-parent household & $\begin{array}{c}-0.2 \\
(0.02)^{* * *}\end{array}$ & $\begin{array}{c}-0.19 \\
(0.02)^{* * *}\end{array}$ & $\begin{array}{c}-0.19 \\
(0.02)^{* * *}\end{array}$ \\
\hline Dummy for presence of younger sister & $\begin{array}{c}0.21 \\
(0.01)^{* * *}\end{array}$ & $\begin{array}{c}0.21 \\
(0.01)^{* * *}\end{array}$ & $\begin{array}{c}0.21 \\
(0.01)^{* * *}\end{array}$ \\
\hline Dummy for presence of younger brother & $\begin{array}{c}0.2 \\
(0.01)^{* * *}\end{array}$ & $\begin{array}{c}0.2 \\
(0.01)^{* * *}\end{array}$ & $\begin{array}{c}0.2 \\
(0.01)^{* * *}\end{array}$ \\
\hline Dummy for presence of older sister & $\begin{array}{c}-0.03 \\
(0.01)^{* *}\end{array}$ & $\begin{array}{c}-0.03 \\
(0.01)^{* *}\end{array}$ & $\begin{array}{c}-0.03 \\
(0.01)^{* *}\end{array}$ \\
\hline Dummy for presence of older brother & $\begin{array}{c}0.07 \\
(0.01)^{* * *}\end{array}$ & $\begin{array}{c}0.07 \\
(0.01)^{* * *}\end{array}$ & $\begin{array}{c}0.07 \\
(0.01)^{* * *}\end{array}$ \\
\hline Dummy if entrepreneur & & $\begin{array}{c}-1.58 \\
(0.37)^{* * *}\end{array}$ & $\begin{array}{l}0.05 \\
(3.4)\end{array}$ \\
\hline $\begin{array}{l}\text { Interaction of entrepreneur and household } \\
\text { income per capita }\end{array}$ & & $\begin{array}{c}0.14 \\
(0.05)^{* * *}\end{array}$ & $\begin{array}{l}-0.06 \\
(0.43)\end{array}$ \\
\hline $\begin{array}{l}\text { Interaction of entrepreneur and parental } \\
\text { education }\end{array}$ & & $\begin{array}{c}0.03 \\
(0.01)^{* *}\end{array}$ & $\begin{array}{c}0.04 \\
(0.03)\end{array}$ \\
\hline Constant & $\begin{array}{c}1.29 \\
(0.07)^{* * *}\end{array}$ & $\begin{array}{c}1.33 \\
(0.08)^{* * *}\end{array}$ & $\begin{array}{c}1.28 \\
(0.14)^{* * *}\end{array}$ \\
\hline$R^{2}$ & 0.11 & 0.11 & 0.11 \\
\hline Observations & 26,694 & 26,694 & 26,694 \\
\hline
\end{tabular}


status and the schooling gap shown in column 2 (OLS estimation) that increases in magnitude for the IV estimations (column 3). These results show that belonging to a family with entrepreneurial activities reduces the schooling gap for children after education is mandatory, thus increasing intergenerational social mobility.

Because of space restrictions, in tables 8 and 9 we report only the coefficients of interest for equations (1) and (4) described above (income, education and the appropriate interactions) for every year

Table 7. Schooling gap in 2006, OLS estimation results, nonmandatory education

\begin{tabular}{|c|c|c|c|}
\hline & $\begin{array}{l}\text { (1) } \\
\text { OLS }\end{array}$ & $\begin{array}{l}(2) \\
\text { OLS }\end{array}$ & $\begin{array}{l}\text { (3) } \\
\text { IV }\end{array}$ \\
\hline Household income per capita & $\begin{array}{c}-0.59 \\
(0.04)^{* * *}\end{array}$ & $\begin{array}{c}-0.58 \\
(0.04)^{* * *}\end{array}$ & $\begin{array}{c}-0.99 \\
(0.08) * * *\end{array}$ \\
\hline Maximum level of parental education & $\begin{array}{c}-0.3 \\
(0.01)^{* * *}\end{array}$ & $\begin{array}{c}-0.3 \\
(0.01)^{* * *}\end{array}$ & $\begin{array}{c}-0.27 \\
(0.01)^{* * *}\end{array}$ \\
\hline Dummy for single-parent household & $\begin{array}{c}-0.34 \\
(0.07)^{* * *}\end{array}$ & $\begin{array}{c}-0.32 \\
(0.07)^{* * *}\end{array}$ & $\begin{array}{c}-0.26 \\
(0.08)^{* * *}\end{array}$ \\
\hline Dummy for presence of younger sister & $\begin{array}{c}0.07 \\
(0.05)\end{array}$ & $\begin{array}{c}0.07 \\
(0.05)\end{array}$ & $\begin{array}{c}0 \\
(0.05)\end{array}$ \\
\hline Dummy for presence of younger brother & $\begin{array}{c}0.18 \\
(0.05)^{* * *}\end{array}$ & $\begin{array}{c}0.18 \\
(0.05)^{* * *}\end{array}$ & $\begin{array}{c}0.15 \\
(0.05)^{* * *}\end{array}$ \\
\hline Dummy for presence of older sister & $\begin{array}{c}-0.93 \\
(0.07)^{* * *}\end{array}$ & $\begin{array}{c}-0.94 \\
(0.07)^{* * *}\end{array}$ & $\begin{array}{c}-0.99 \\
(0.07)^{* * *}\end{array}$ \\
\hline Dummy for presence of older brother & $\begin{array}{c}-0.77 \\
(0.06)^{* * *}\end{array}$ & $\begin{array}{c}-0.77 \\
(0.06)^{* * *}\end{array}$ & $\begin{array}{c}-0.77 \\
(0.07)^{* * *}\end{array}$ \\
\hline Dummy if entrepreneur & & $\begin{array}{c}-2.85 \\
(1.06)^{* * *}\end{array}$ & $\begin{array}{c}-54.52 \\
(8.51)^{* * *}\end{array}$ \\
\hline $\begin{array}{l}\text { Interaction of entrepreneur and household } \\
\text { income per capita }\end{array}$ & & $\begin{array}{c}0.19 \\
(0.14)\end{array}$ & $\begin{array}{c}6.58 \\
(1.05)^{* * *}\end{array}$ \\
\hline $\begin{array}{l}\text { Interaction of entrepreneur and parental } \\
\text { education }\end{array}$ & & $\begin{array}{c}0.08 \\
(0.03)^{* * *}\end{array}$ & $\begin{array}{c}-0.22 \\
(0.06)^{* * *}\end{array}$ \\
\hline Constant & $\begin{array}{c}10.88 \\
(0.26)^{* * *}\end{array}$ & $\begin{array}{c}10.88 \\
(0.27)^{* * *}\end{array}$ & $\begin{array}{c}13.78 \\
(0.55)^{* * *}\end{array}$ \\
\hline$R^{2}$ & 0.22 & 0.22 & 0.11 \\
\hline Observations & 16,567 & 16,567 & 16,567 \\
\hline
\end{tabular}


covered in this study. In the basic regressions for mandatory and nonmandatory education, there are two clear patterns: The estimated coefficient of income decreases over time, while the coefficient of parents' educational attainment grows. Therefore, this information alone is insufficient to assess the impact of family background and inter-generational social mobility. In all regressions, the income and education variable have the expected sign and are significant. The size of the income coefficient in non-mandatory education is much greater than the education coefficient, which is reasonable since the SG in non-mandatory education is larger than in mandatory education.

The impact of entrepreneurship on the SG, especially in non-mandatory education ages, is not obvious. It may be that young adults whose parents are entrepreneurs quit school before age 23 to participate in the family business, or it may be the case that the children of entrepreneurs can afford to remain at home and continue studying.

In Uruguay, the public school system was developed early, such that by the final decades of the $19^{\text {th }}$ century, primary education was already mandatory and free. Therefore, we would expect the effect of entrepreneurship and social differences to be larger for the SG of students ages 16-23. The net effect of entrepreneurship, i.e., the sum of the coefficient of household income plus the interaction of entrepreneurship with household income, gives a lower weight to family background characteristics. Thus, the social mobility index for entrepreneurs is higher.

The last two columns in tables 8 and 9 show the interaction with entrepreneurship. In almost all years, at least one of the interactions with the two family background variables is statistically significant. In all cases, the interactions have a positive sign, suggesting that for entrepreneurs family background has a lower impact on SG than for non-entrepreneurs, i.e., inter-generational mobility captured by the SMI should be higher for entrepreneurs.

We found that there are at least as many statistically significant interactions of entrepreneurship for non-mandatory education as for mandatory education. This suggests that although Uruguay requires a standard number of years of education for everyone, there may be quality differences in the education received, and the children of entrepreneurs may have access to higher-quality education; this could perhaps be from private schools that are inaccessible to other families. We previously argued that in the Uruguayan education system, enrollment and retention problems become prominent in secondary school, which at first glance 


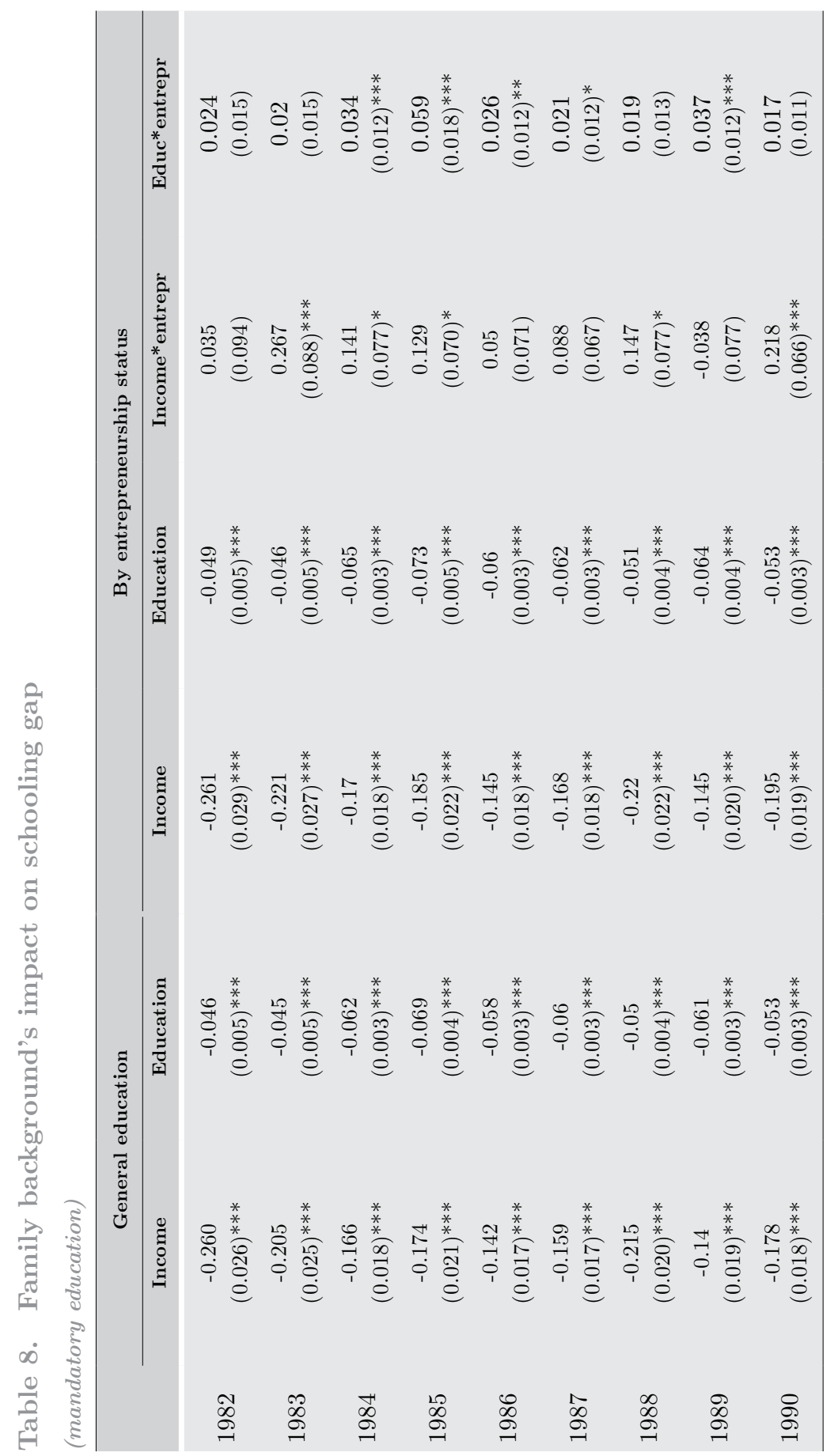




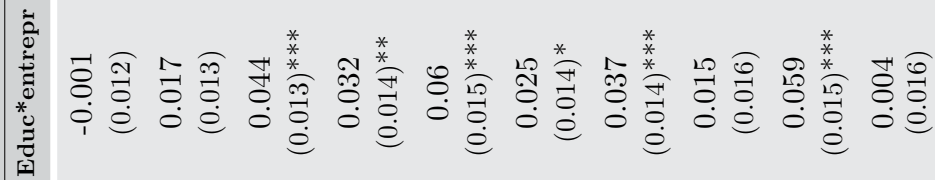

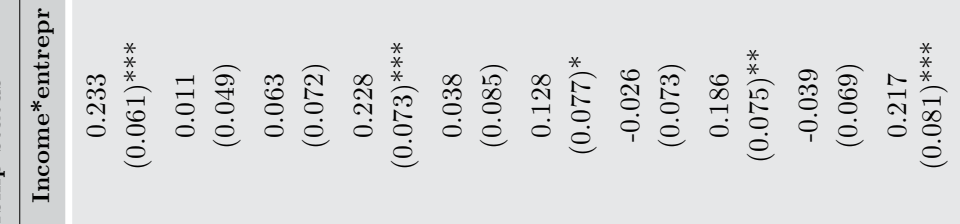

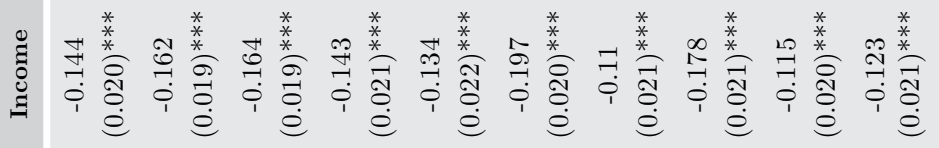

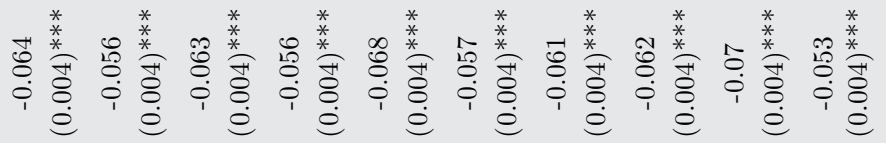

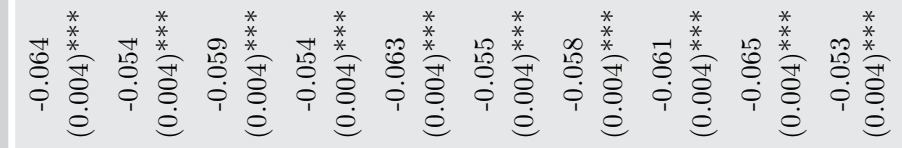

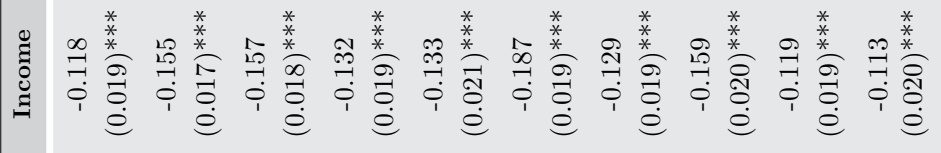

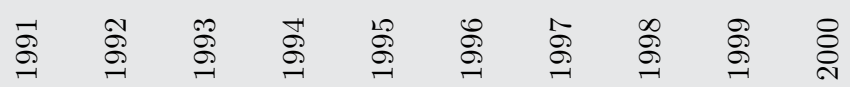




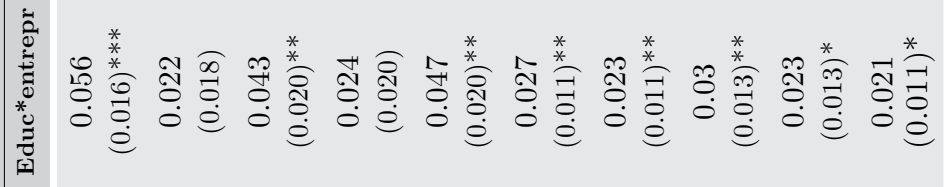

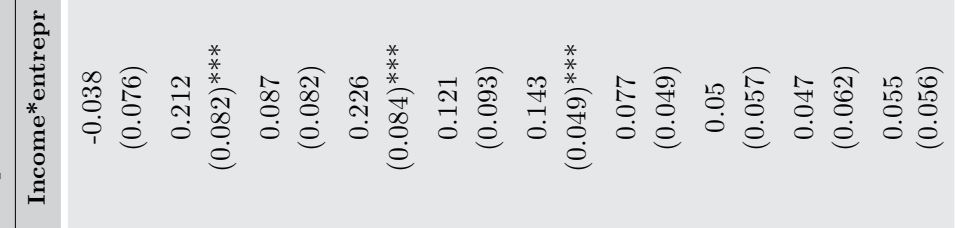

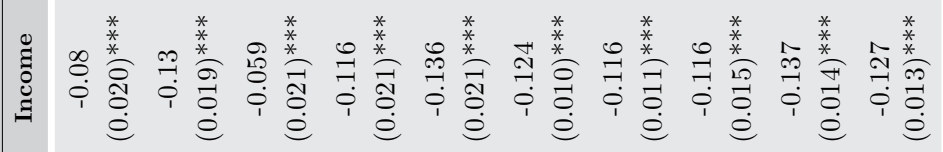

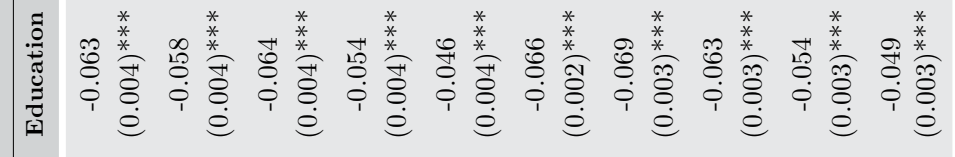

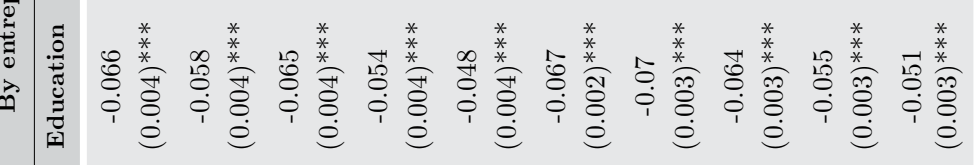




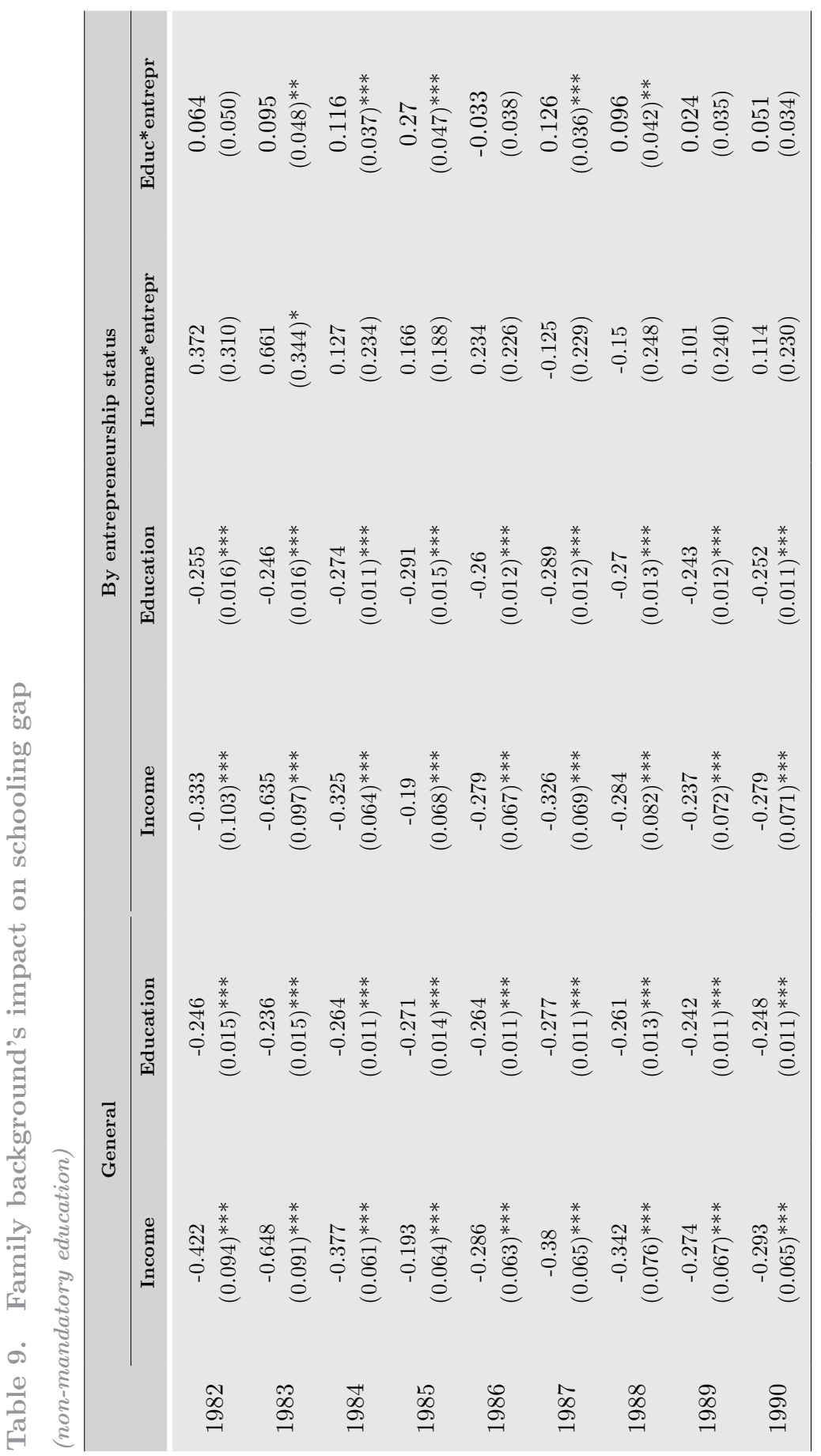




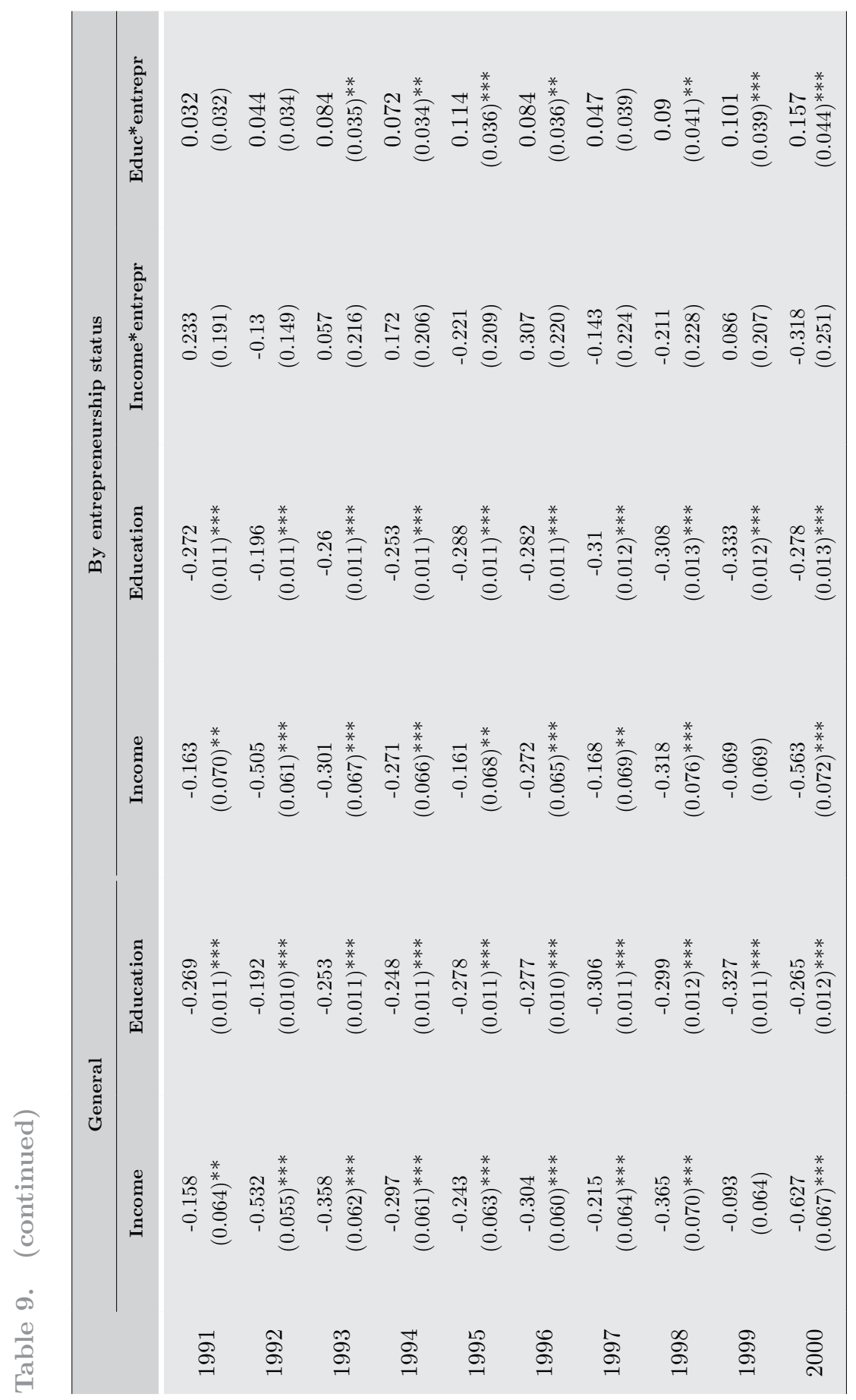


苛

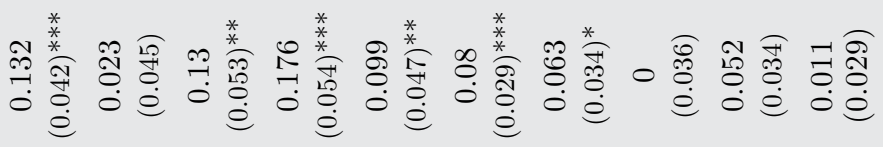

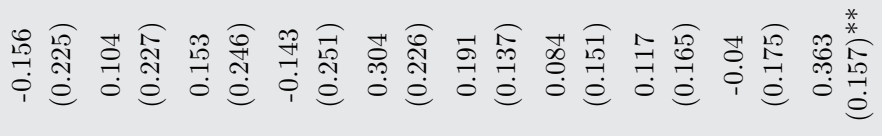

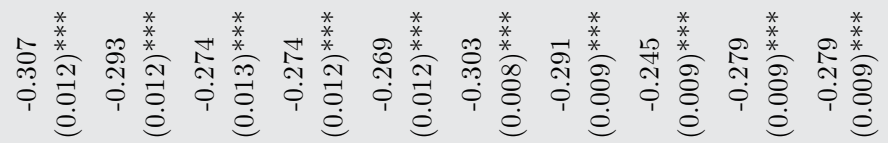

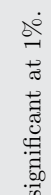

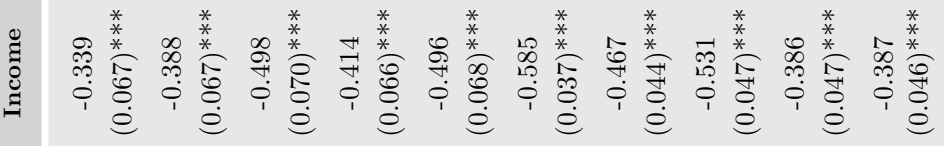

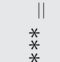

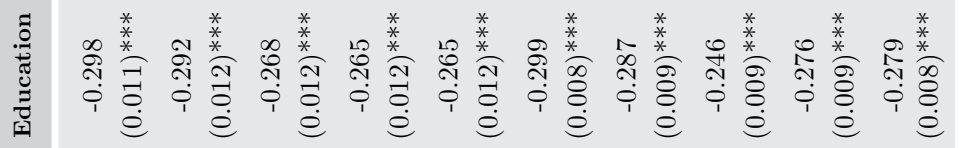

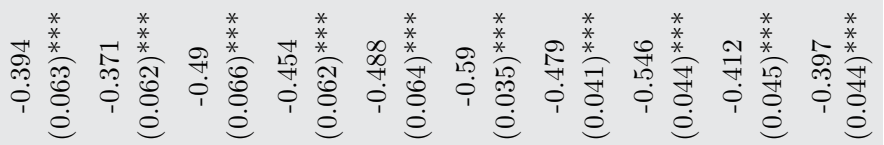

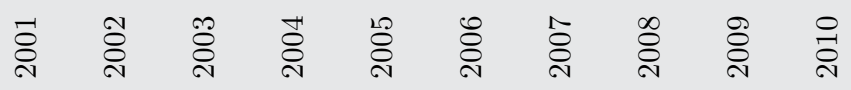


may seem related to what secondary school offers to students. The results found for mandatory years of education for entrepreneurship, however, suggest a different explanation: Problems in secondary school may originate in quality differentials during earlier years of the student's formation, probably during primary school. These problems, therefore, are the cause of the differentials in inter-generational social mobility.

Figures 4 and 5 illustrate our calculations of the SMI and its $95 \%$ confidence interval for the two age brackets analyzed, summarizing graphically the data presented in tables 8 and 9 for a better appreciation of the time variation. Andersen (2001) and Conconi et al. (2008) computed the SMI for several Latin American countries, coinciding in their findings that Uruguay is among the top three countries with the highest mobility in Latin America. Our results are analogous to theirs.

The SMI for mandatory education (between 6 and 15 years old), is very stable in the range of $0.89-0.92$ for the entire period considered. According to this index, there would be no changes in mobility, but this finding must be tempered with the caveat that because education is mandatory, family background becomes less important than institutional factors.

During the period considered, the SMI for non-mandatory education varies from 0.78 to 0.90 . It could be argued that for those aged 16-23,

Figure 4. Social mobility index

(mandatory education)

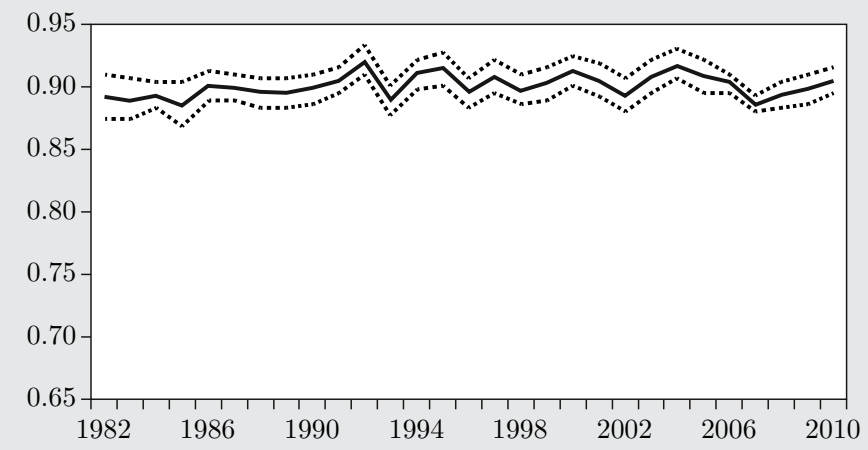


Figure 5. Social mobility index

(non-mandatory education)

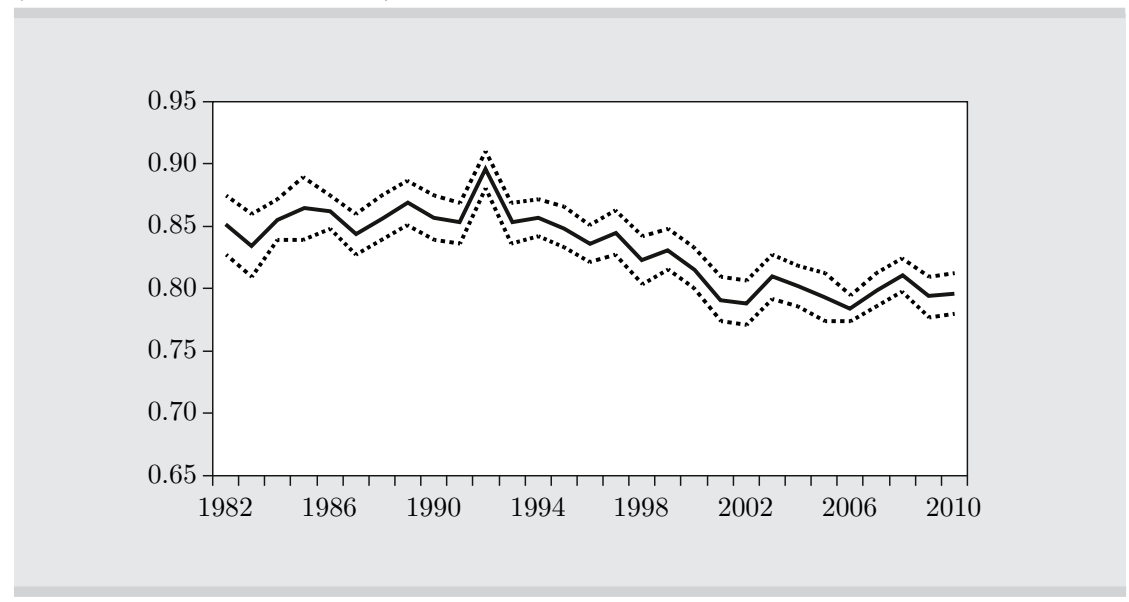

Source: Authors' calculations based on household surveys.

year olds, family background loses importance as the individual gains autonomy, such that family variables become less relevant to explaining educational outcomes. It could also be argued that for this group parents are neither subject to laws nor provided with financial incentives, so there is no stigma attached to not sending children to school. Therefore, generally those parents with a clear understanding of the importance of education will influence their children to continue their studies. An understanding of the importance of education is not particular to any single social group but probably correlates with better education and socioeconomic background of the parents, thus increasing the relevance of family background in determining educational outcomes. While the net effect of these two forces is ambiguous, we find that the SMI for the 16-23 age bracket is smaller than for the younger group at conventional statistically significant levels for most of the years under study, a finding that suggests that the second effect dominates.

We also find that the SMI for ages 16-23 consistently declined during the period studied to reach its minimum level in 2001, implying a decrease in the levels of social mobility in the country. This is in line with concerns about increased segmentation of Uruguayan society and a worsening of the educational system as an opportunity-equalizing device. During the last decade, however, social mobility in the case of non-mandatory education seems to have stabilized at about 0.80 . 
The evolution of the SMI for entrepreneurs and non-entrepreneurs (not reported) follows the same evolution as for the population as a whole (showing more mobility for entrepreneurs).

\subsection{Results from inequality of opportunity calculations}

We report the IOp results for mandatory and non-mandatory education in Figure 6. While the set of family background characteristics included in our explanation of the SG accounts for about 0.11 of its variance in mandatory education and is stable throughout the period of study, those characteristics account for about 0.19 in non-mandatory education, and show a tendency to increase over time. This is consistent with the SMI findings.

\section{Figure 6. Inequality of opportunity}

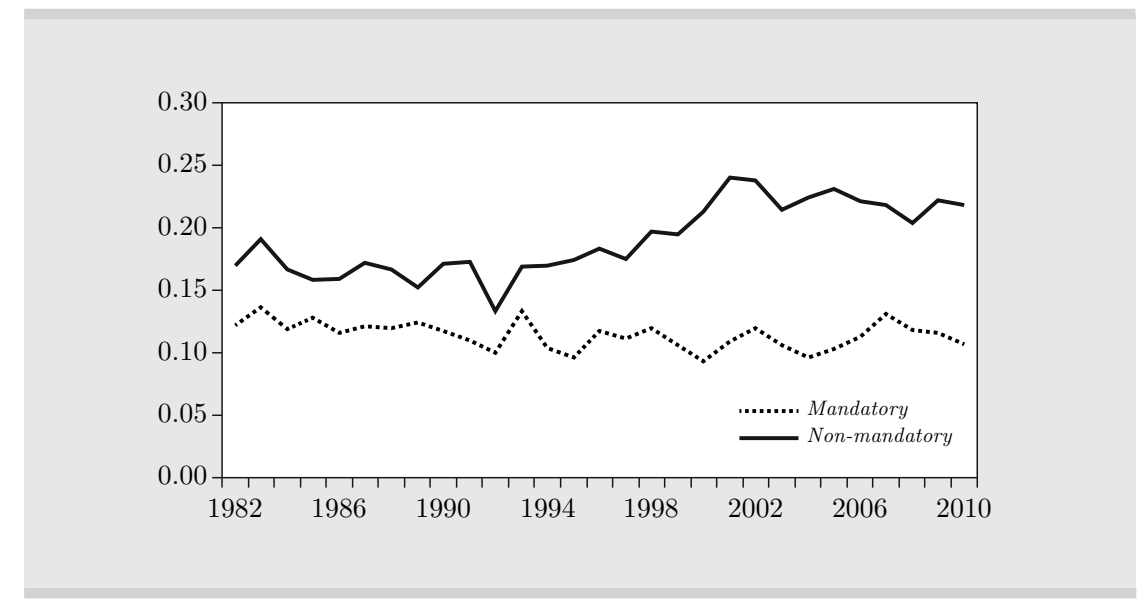

Source: Authors' calculations based on household surveys.

\section{CONCLUDING REMARKS}

In this paper we study the impact of parents' educational attainment and income on children's education in Uruguay between 1982 and 2010, using educational mobility as a proxy for inter-generational social mobility.

The transition matrices computed show decreasing levels of mobility in the time period studied. Thus, it is increasingly probable that the children of those with more education will be among the more educated. 
Improvements in access to higher education over the period were unevenly distributed among social sectors, with most of the increase in access to higher education seen in the most affluent sectors.

We also computed an index of social mobility that reflects how much of children's educational outcome, or SG, is explained by the parents' schooling and income. We found that while there were no changes in the index for mandatory education, there was a decrease, or lower mobility for non-mandatory education, i.e., the last three years of high school and university attendance. Therefore, the evidence suggests that inter-generational social mobility in Uruguay has fallen and there are risks of increased social segmentation. The overall picture suggests that during the mandatory education years, the Uruguayan public education system has been an equalizing device. Beyond the mandatory years, however, the educational system evolved to produce a worsening in inter-generational mobility starting in the 1990s. This evidence, together with the transition matrices, suggests that the more significant enrollment and retention problems are at the secondary education level.

Institutional and social pressures are stronger for mandatory education than for non-mandatory education, which is why we expected entrepreneurship to have stronger effects in later years. Consistently, we found stronger results for non-mandatory education (especially after controlling for the endogeneity of entrepreneurship), i.e., compared to non-entrepreneur families, families of entrepreneurs have more impact on improving the education of their children at higher levels. We conjecture that although the public school system in Uruguay successfully provides primary education for all and that this is also true to a somewhat lesser extent for the first years of secondary school, there are important differences in the quality of education provided for different groups of children.

Finally, a somewhat different perspective on our results is that entrepreneurship is indeed a channel for higher inter-generational social mobility. This quantitative evidence affirms the anecdotal evidence of immigrants - individuals with low levels of education but with tremendous creative spirit - who progressed, ascended socially, and provided better living conditions for their descendants. Although Uruguay long ago stopped receiving waves of immigrants, the potential of entrepreneurship as a mobility device still exists. 


\section{REFERENCES}

Acemoglu, D. and F. Zilibotti (1997). "Was Prometheus unbound by chance? Risk, diversification, and growth," Journal of Political Economy 105(4): 709-51.

Acs, Z. (2006). "How is entrepreneurship good for economic growth?" Innovations Journal, Winter.

Andersen, L.E. (2001), "Social mobility in Latin America: Links with adolescent schooling." Inter-American Development Bank, Latin American Research Network Working Paper R-433.

Angrist, J. and J.S. Pischke (2009), Mostly harmless econometrics: An empiricist's companion, Princeton: Princeton University Press.

Azevedo, V. and C. Bouillon (2010), "Intergenerational social mobility in Latin America: A review of existing evidence," Revista de Análisis Económico 25(2): 7-42.

Banerjee, A. and E. Duflo (2007), "What is middle class about the middle classes around the world?" CEPR Discussion Paper 6613.

Behrman, J., N. Birdsall, and M. Székely (1999), "Intergenerational mobility in South America: Deeper markets and better schools make a difference," in N. Bridsall and C. Graham, eds., New markets, new opportunities? Economic and social mobility in a changing world. Washington, D.C.: Brookings Institution and Carnegie Endowment for International Peace.

Bukstein, D. and C. Sapelli (2011), "Educación y crecimiento," BCU Working Paper Series.

Bukstein, D., and N. Gandelman (2014), "Intra-generational social mobility and entrepreneurship in Uruguay," Latin American Journal of Economics 51(2): $227-245$.

Conconi A., G. Cruces, S. Olivieri, and R. Sánchez (2008), "E pur si muove? Movilidad, pobreza y desigualdad en América Latina," Económica, 54(1-2): 121-59.

Ferreira F.H.G. and J. Gignoux (2011), "The measurement of educational inequality: Achievement and opportunity," World Bank Policy Research Working Paper 5873 and Paris School of Economics WP 2011-38.

Fields, G.S. (2003) "Accounting for income inequality and its change: A new method, with application to the distribution of earnings in the United States," Research in Labor Economics 22: 1-38.

Haveman, R. and B. Wolfe. (1995), "The determinants of children's attainments: A review of methods and findings," Journal of Economic Literature 33(4): $1829-78$.

Holmlund, H., M. Lindahl, and E. Plug (2011), "The causal effect of parent's schooling on children's schooling," Journal of Economic Literature 49(3): $615-51$. 
Kantis, H., J. Federico, and L.A. Trajtenberg (2012), "Entrepreneurship, economic mobility and entrepreneurial propensity. A regional view based on the analysis of selected Latin American countries," IADB Working Paper Series 315.

Lopez-Calva, L. and E. Ortiz-Juarez (2011), "A vulnerability approach to the definition of the middle class," World Bank Policy Research Working Paper 5902.

OECD (2011) Latin American Economic Outlook. OECD Development Centre.

Shorrocks, Anthony F. (1982), "Inequality decomposition by factor components," Econometrica 50: 193-211.

Vegas, E. and J. Petrow (2008), Raising Student Learning in Latin America. The World Bank. 